\title{
The Role of Integrated Nutrient Management System for Improving Crop Yield and Enhancing Soil Fertility under Small Holder Farmers in Sub-Saharan Africa: A Review Article
}

\author{
GeremewBiramo* \\ Southern Agricultural Research Institute, Ethiopia \\ *Corresponding author: GeremewBiramo, Southern Agricultural Research Institute, Arbamich Agricultural Research Center, P.O.Box, 05 Arbaminch, \\ Ethiopia
}

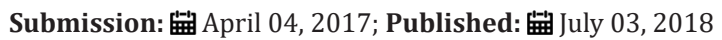

\begin{abstract}
Fertilizer usage plays a major role in the universal need to increase food production to meet the demands of the growing world population. Fertilizer application resulted in marked crop yield increases, which for most crops were more than hundred. The extent to which fertilizers are used still differs considerably between various regions of the world. Mostly in Ethiopia Urea and DAP are the only fertilizers that are used in agricultural productivity. But using balanced fertilizers has an impact on plant growth and physicochemical properties of soil. Due to the continuous decrease in organic matter and nutrient content of the soil, the importance of integrated nutrient management for efficient utilization of nutrient resources and for long-term maintenance of soil fertility has been indicated. Therefore, the aim of this review was to review the role of integrated nutrient management for improving crop yield and enhancing soil fertility under small holder farmers in sub-Saharan Africa, especially in Ethiopia and recommend the appropriate approaches for enhancing soil fertility and increasing crop yield for small holder farmers in sub-Saharan Africa, especially in Ethiopia. So, the results of this review showed that, the integrated application of organic and inorganic fertilizers improve productivity of crops as well as the fertility status of the soil. Nevertheless, though ISFM is the notably preferred option in replenishing soil fertility and enhancing productivity, it is not yet widely taken up by farmers. The reasons for this are many, which include access or availability of inputs, use of organic resources for other purposes in place of soil fertility, nutrient balancing, collecting, transporting and management of organic inputs and economic returns of investments. These are the key challenges of adoption in the scaling up of such alternative soil fertility management practices to millions of small-scale farmers in the country. There is a need, therefore, for research and extension to sort out issues of adoption and scaling up of the available options. In order to address soil fertility problems, potential synergies can be gained by combining technical options with farmers' knowledge as well as training of farmers and development agent on new soil fertility management approaches.
\end{abstract}

Keywords: Fertilizer; Integrated nutrient management; ISFM; Adoption

\section{Introduction}

Agriculture is the basis of the Ethiopian economy, accounting for $46 \%$ of its GDP and $90 \%$ of its export earnings and employing $85 \%$ of the countries labour force [1,2]. Increasing agricultural productivity is absolutely necessary to feed the increasing population by increasing land productivity [3]. Most of the Ethiopian soils are low nutrient content due to erosion and absence of nutrient recycling. On the contrary, most of the areas used for production of grains especially teff, wheat and barley fall under the low fertility soils [4]. Soils in the highlands of Ethiopia usually have low levels of essential plant nutrients and organic matter content, especially low availability of nitrogen and phosphorus has been demonstrated to be major constraint to cereal production [5].

Fertilizer usage plays a major role in the universal need to increase food production to meet the demands of the growing world population. Fertilizer application resulted in marked crop yield increases, which for most crops was more than hundred percent. The extent to which fertilizers are used still differs considerably between various regions of the world. Mostly in Ethiopia Urea and DAP are the only fertilizers that are used in agricultural productivity. But using balanced fertilizers has an impact on plant growth and physicochemical properties of soil.

Soil nutrient status is widely constrained by the limited use of inorganic and organic fertilizers and by nutrient loss mainly due to erosion and leaching [6]. Many small holder farmers do not have access to synthetic fertilizer because of high price of fertilizers, lack of credit facilities, poor distribution, and other socio-economic factors. Consequently, crop yields are low, in fact decreasing in many areas, and the sustainability of the current farming system is at risk 
[6]. Ethiopia is one of the 14 sub-Saharan countries with highest rates of nutrient depletion [7]. Due to lack of adequate synthetic fertilizer input, limited return of organic residues and manure, and high biomass removal, erosion, and leaching rates.

Modern nutrient management strategy has shifted its focus toward the concept of sustainability and eco-friendliness. Integrated use of various soil fertility amendment inputs aims at alleviating the limiting nutrients problem and improving their availability through interactions with the mineral soil and reducing the P sorption capacity of the soil [8]. The same authors, however, reported that crop yields still fall short of their potential because of inadequate nutrient inputs, inappropriate quality of the organic materials, and inefficient combination, among other causes of yield reduction. Due to the continuous decrease in organic matter and nutrient content of the soil, the importance of integrated nutrient management for efficient utilization of nutrient resources and for long-term maintenance of soil fertility has been indicated [9]. Therefore, the aim of this review was to review the role of integrated nutrient management for improving crop yield and enhancing soil fertility under small holder farmers in sub-Saharan Africa, especially in Ethiopia and recommend the appropriate approaches for enhancing soil fertility and increasing crop yield for small holder farmers in sub-Saharan Africa, especially in Ethiopia.

\section{Literature Review}

\section{Effects of organic fertilizer sources}

The most common strategy for coping soil infertility problem is the use of inorganic fertilizer ( $\mathrm{N}$ and $\mathrm{P}$ ) available in the market. But this strategy is highly constrained by high cost, low purchasing power of smallholders and limited access to credit, and environmental problems. Thus, a strategy that also considers the available resources like organic resources (green manure) needs to be developed. But the contribution of organic sources of nutrients for crop production is limited by their low nutrient content, requiring large amounts to meet moderate yield increases [9]. In densely populated areas, large amounts of organic residues can't be produced on small farms and where the entire area has to be devoted to food crop production.

The use of organic manure as a fertilizer in less developed countries like Ethiopia has received much attention from economic point of view. In view of the current worldwide shortage of chemical fertilizers and its anticipated adverse effect on food production, the endeavor to discover and develop efficienttechniques of utilizing organic materials as fertilizer is urgently needed. Organic fertilizers were regarded as important, but it was realized that organic fertilizers would not be available in sufficient amounts to increase food production drastically [10]. According to Shalini et al. application of organic manures increased uptake of N, P and K over application of inorganic fertilizers alone. The authors also revealed that integration of organic with inorganic fertilizer had a marked effect in increasing growth and also in maintaining soil fertility and availability of nutrients in soil after harvest. The result of several long-term experiments in different cropping systems also revealed that, long-term sustainability of productivity in intensive cropping system could be achieved only through integration of inorganic and organic source of nutrients.

Farmyard manure (FYM) is among the important soil amendments to which farmers have access in mixed farming system. In addition to its nutrient supply, farmyard manure improves the physicochemical conditions of soils. According to Beukema and Van der Zaag, the crop benefits from the application of FYM not only from the amounts of nitrogen, phosphorus and potassium it contains but also from its improving effects on the tilth and the moisture retaining properties of the soil [11]. Increased yields of cereal and other crops due to application of FYM have been reported by Hegde. Tolessa also revealed that there was significant increase in total nitrogen, available phosphorus and potassium content of the soil with increases in FYM levels from 8 to 24t/ha (Table 1).

Table 1: Effect of organic fertilizers application on growth of tomatoes in the first Season $(2009 / 2010)$.

\begin{tabular}{|c|c|c|c|c|c|c|c|c|}
\hline \multicolumn{9}{|c|}{ Tomatoes Growth Parameters } \\
\hline Treatments & $\begin{array}{c}\text { Plant } \\
\text { height(cm) }\end{array}$ & $\begin{array}{c}\text { Days to } \\
\qquad \mathbf{5 0 \%} \\
\text { flowering }\end{array}$ & $\begin{array}{c}\text { Number } \\
\text { of } \\
\text { branches }\end{array}$ & $\begin{array}{c}\text { Root } \\
\text { length }(\mathrm{cm})\end{array}$ & $\begin{array}{l}\text { Fresh } \\
\operatorname{root}(g)\end{array}$ & $\begin{array}{c}\text { Dry } \\
\operatorname{root}(g)\end{array}$ & 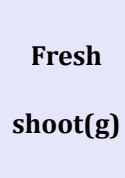 & $\begin{array}{c}\text { Dry } \\
\text { shoot (g) }\end{array}$ \\
\hline Compost & $61.0^{\mathrm{a}}$ & 68 & $18.0^{\mathrm{a}}$ & $18.6^{\mathrm{d}}$ & $52.0^{\mathrm{a}}$ & $10.4^{\mathrm{a}}$ & $186.6^{\mathrm{a}}$ & $51.8^{\mathrm{a}}$ \\
\hline Cattle manure & $50.0^{c}$ & 71 & $14.0^{\mathrm{b}}$ & $22.1^{\mathrm{b}}$ & $43.8^{\mathrm{b}}$ & $8.2^{\mathrm{bc}}$ & $173.4^{c}$ & $45.5^{\mathrm{c}}$ \\
\hline Chicken manure & $52.0^{\mathrm{bc}}$ & 73 & $15.0^{\mathrm{b}}$ & $23.3^{\mathrm{b}}$ & $44.9^{\mathrm{b}}$ & $8.4^{\mathrm{bc}}$ & $174.1^{\mathrm{c}}$ & $46.7^{\mathrm{c}}$ \\
\hline Chicken + Cattle & $57.0^{\mathrm{b}}$ & 69 & $18.0^{\mathrm{a}}$ & $20.8^{c}$ & $48.5^{\mathrm{b}}$ & $9.3^{\mathrm{b}}$ & $181.1^{\mathrm{b}}$ & $48.6^{\mathrm{b}}$ \\
\hline Control & $41.0^{\mathrm{d}}$ & 82 & $11.0^{c}$ & $26.4^{\mathrm{a}}$ & $30.4^{\mathrm{c}}$ & $5.5^{\mathrm{d}}$ & $140.9^{\mathrm{d}}$ & $32.4^{\mathrm{d}}$ \\
\hline
\end{tabular}




\begin{tabular}{|c|c|c|c|c|c|c|c|c|}
\hline Mean & 52 & 73 & 15 & 22.2 & 43.92 & 8.35 & 171.2 & 45 \\
\hline $\mathrm{SE} \pm$ & $0.87^{* *}$ & $0.71^{* *}$ & $0.49^{* *}$ & $0.34^{* *}$ & $0.95^{* *}$ & $0.25^{* *}$ & $2.05^{* *}$ & $0.86^{* *}$ \\
\hline $\mathrm{CV}(\%)$ & 3.53 & - & 7.16 & 5.48 & 2.2 & 3.29 & 1.65 & 2.08 \\
\hline
\end{tabular}

** Significant at $(\mathrm{P} \leq 0.01)$ level. a, b, c, d means in the same column under the same factor with different letters are significantly different according to Duncan Multiple Range Test (DMRT).

Table 2: Effects of organic fertilizers application on tomatoes yield in the first Season $(2009 / 2010)$.

\begin{tabular}{|c|c|c|c|c|}
\hline Treatments & Fruits (No./plant) & Fruits marketable yield (kg) & Weight of 10 fruits (kg) & Fruit yield (ton/ha) \\
\hline Compost & $36.0^{\mathrm{a}}$ & $11.3^{\mathrm{a}}$ & $1.1^{\mathrm{a}}$ & $21.5^{\mathrm{a}}$ \\
\hline Cattle manure & $31.0^{\mathrm{bc}}$ & $6.1^{\mathrm{b}}$ & $0.8^{\mathrm{c}}$ & $13.6^{\mathrm{c}}$ \\
\hline Chicken manure & $30.0^{\mathrm{c}}$ & $6.7^{\mathrm{b}}$ & $0.9^{\mathrm{bc}}$ & $16.1^{\mathrm{bc}}$ \\
\hline Chicken + Cattle & $34.0^{\mathrm{ab}}$ & $9.3^{\mathrm{a}}$ & $1.0^{\mathrm{b}}$ & $19.4^{\mathrm{ab}}$ \\
\hline Control & $16.0^{\mathrm{d}}$ & $3.7^{\mathrm{c}}$ & $0.5^{\mathrm{d}}$ & $10.0^{\mathrm{d}}$ \\
\hline Mean & 29.5 & 7.4 & 0.9 & 16.1 \\
\hline SE \pm & $0.92^{* *}$ & $0.46^{* *}$ & $0.02^{* *}$ & $0.27^{* *}$ \\
\hline CV (\%) & 6.24 & 14.61 & 7.62 & 15.55 \\
\hline
\end{tabular}

** Significant at $(\mathrm{P} \leq 0.01)$ level, a, b, c, d, e means in the same column under the same factor with different letters are significantly different according to Duncan Multiple Range Test (DMRT).

The data in Table 2 represent the yield parameters in the first season (2009/10). All measured parameters gave highly significant differences $(\mathrm{P} \leq 0.01)$ among treatments. Tomato yield was positively affected by organic fertilizers application. Compost and chicken plus cattle manure gave the highest yield parameters compared to other treatments. Compost gave the highest values of number fruits/plant (36 fruits), fruits marketable yield (11.3kg); and fruits yield (21.5tha $\left.{ }^{1}\right)$. Compost increased fruits yield by (112\%) as compared to the untreated control [12]. The lowest values of tomato yield parameters were obtained in the untreated control, which gave fruits number/plant (16 fruits), fruits marketable yield (3.7kg), and fruits yield (10ton \ha).

A Cajanus biomass transfer study conducted on hybrid maize variety (BH-660) at Bako in western Oromia revealed that applying 4 tha $^{-1}$ biomass can give a yield advantage of about $87 \%$ over that of the control plot (without both organic and inorganic fertilizer), but less only by $17 \%$ from the standard plot (plot that received recommended rate) (Abebe and Diriba, in press). This study gave base line information about the potential of Cajanus biomass transfer for boosting maize yield in hybrid varieties.

There are few studies on utilization of poultry manure in tomato production in Nigeria, and information about effects on soil physical properties and nutrient uptake, and sustainability of tomato production systems is scarce. Adediran et al. compared poultry manure, household, market and farm waste and found that poultry manure at 20 tha $^{-1}$ had highest nutrient contents and mostly increased yield of tomato and soil macro and micronutrients content [13]. Akande and Adediran found that poultry manure at 5tha ${ }^{-1}$ significantly increased tomato and dry matter yield, soil $\mathrm{pH}$, $\mathrm{N}, \mathrm{P}, \mathrm{K}, \mathrm{Ca}$ and $\mathrm{Mg}$ and nutrient uptakes.
Aluko et al. found little information on the effects of organic waste on soil physical properties and they observed that poultry manure incorporation had no significant effect on soil density and porosity.

\section{Effects of inorganic fertilizer sources}

Inorganic fertilizers are very important in the cultivation of crops and are increasingly used. This increase is due to shortage of animal manures and residues and to the increasing knowledge of their value. Inorganic fertilizers will remain a key component of soil fertility management and an essential element of any agricultural development strategy or plan to increase food production. Various reports showed that use of inorganic fertilizers in the tropics had stagnated, and this was explained by poor marketing and inadequate profitability from inorganic fertilizer use [14]. According to Muriithi et al. application of inorganic fertilizer in the form of DAP at the rates of $90 \mathrm{kgNha}^{-1}+230 \mathrm{~kg}_{2} \mathrm{O}_{5}$ significantly increased the vigour of the potato plants compared to the other treatment. The results also indicated that there were significant responses to application of inorganic fertilizer to the maize crop when compared to the use of FYM alone.

Fertilizer experiments in most potato growing areas indicated $\mathrm{N}$ nutrient requirement of potato to be very high. Nitrogen fertilizer is generally needed because of its mobility in soils and the large amounts needed by the plant. Potato yield, however, can be adversely affected by both insufficient and excess soil N. High soil N delays tuber initiation and promotes excessive vegetative growth at the expense of tubers. Thus, addition of $\mathrm{N}$ above the recommended rate did not increase yield and even reduced it for late maturing varieties mainly because of delayed tuber enlargement period. Similarly, excess phosphorus may disturb the nutrient balance within the plant and decrease both potato yield and quality. 
Globally, nitrogen is considered as the most limiting factor in the crop production and limits yield in non-fertilized agriculture. Nitrogen fertilization contributes significantly to protein content, especially when fertilizer rates satisfy the requirements of both yield and protein formation [15].

An adequate supply of $\mathrm{P}$ early in the life of a plant is important in the development of its reproductive parts. Large quantities of $\mathrm{P}$ are found in seed and fruit, and it is considered essential for seed formation. A good supply of P is associated with increased root growth. P is also associated with early maturity of crops, particularly grain crops. The quality of certain fruit, forage, vegetable, and grain crops is improved, and disease resistance increased when these crops have satisfactory P nutrition.

An experiment was conducted at Sinana district on farmer's field to study the effects of different nitrogen fertilizer rates $(0,23$, 46 and $69 \mathrm{kgha}^{-1}$ ) on crop phenology, yield and yield related traits, nitrogen uptake parameters and grain protein content of durum wheat [16]. The result showed that nitrogen rates had significant effect on yield, yield related traits, nitrogen uptake parameters and protein content. The effect of nitrogen rates on durum wheat crop phenology and yield related traits are given below in Table 3.

Table 3: Effect of nitrogen rates on crop phenology, yield \& yield related traits of durum wheat.

\begin{tabular}{|c|c|c|c|c|c|c|c|c|c|c|}
\hline $\begin{array}{l}\mathrm{N} \text { rates } \\
\left(\mathrm{kg} \mathrm{ha}^{-1}\right)\end{array}$ & DAS & DPM & Pht & SL & BM & HI & SY & GY & TNU & GPC \\
\hline 0 & 82.7 & 136 & $84.5^{\mathrm{c}}$ & $5.9^{\mathrm{b}}$ & $8635^{d}$ & $36^{a}$ & $5646^{\mathrm{d}}$ & $2604^{c}$ & $95^{d}$ & $11.3^{\mathrm{b}}$ \\
\hline 23 & 83.1 & 136 & $86^{b}$ & $6.1^{\mathrm{a}}$ & $10492^{c}$ & $34^{\mathrm{b}}$ & $7039^{c}$ & $3341^{b}$ & $113^{c}$ & $11.3^{b}$ \\
\hline 46 & 82.7 & 137 & $88.2^{\mathrm{a}}$ & $6.2^{\mathrm{a}}$ & $12457^{b}$ & $32^{c}$ & $8609^{b}$ & $4014^{a}$ & $139^{\mathrm{b}}$ & $11.9^{b}$ \\
\hline 69 & 83.1 & 137 & $89.4^{\mathrm{a}}$ & $6.2^{\mathrm{a}}$ & $13871^{\mathrm{a}}$ & $32^{c}$ & $9540^{\mathrm{a}}$ & $3996^{a}$ & $168^{\mathrm{a}}$ & $13^{\mathrm{a}}$ \\
\hline Mean & 82.9 & 136.5 & 87 & 6.1 & 11363.8 & 33.5 & 7708.5 & 3489 & 128.8 & 11.9 \\
\hline $\operatorname{LSD}(\mathrm{P} \leq .05)$ & NS & NS & 1.4 & 0.12 & 1046 & 0.02 & 895 & 928 & 14 & 0.71 \\
\hline
\end{tabular}

$\mathrm{DAS}=$ days to anthesis, $\mathrm{DPM}=$ days to physiological maturity, $\mathrm{Pht}=$ plant height, $\mathrm{SL}=$ spike length, $\mathrm{BM}=$ biomass $y i e l d, \mathrm{HI}=\mathrm{harvest}$ index, $\mathrm{SY}=$ straw yield, $\mathrm{GY}=$ grain yield, $\mathrm{TNU}=$ total $\mathrm{N}$ uptake, $\mathrm{GPC}=$ grain protein content .

The number of days required to anthesis (DAS) i.e. when anther extrudes from the central spikelet of the spike, had varied between 82.7 and 83.1 days. The number of days required to maturing (DPM) had varied between 136 and 137 days. There is no a significant difference was observed both in the days to anthesis (DAS) and days to maturity (DPM) for different rate of nitrogen application. Maximum plant height was observed among $\mathrm{N}$ rate of $69 \mathrm{kgha}^{-1}(89.4 \mathrm{~cm})$ and $46 \mathrm{kgha}^{-1}(88.2 \mathrm{~cm})$ and minimum $(84.5 \mathrm{~cm})$ was observed in the control [17]. The lowest mean spike length was recorded for control treatment and no significant variation was observed in the spike length for different nitrogen rate applications.

The treatments which are applied with $\mathrm{N}$ Fertilizer gave higher biomass yield than control treatment. When we compared to control, biomass mean yield was increased by $21.5 \%, 44.3 \%$ and $60.6 \%$ for 23,46 and $69 \mathrm{kgNha}^{-1}$ treatments, respectively. Nitrogen treatments had reduced harvest index (HI) significantly $(\mathrm{p}<0.05)$ as compared to the control. Reduction in HI relative to the control was $5.9 \%, 12.5 \%$ and $12.5 \%$ for 23,46 and $69 \mathrm{kgNha}^{-1}$ treatments, respectively. Highest straw yield was for the highest $\mathrm{N}$ rate with yield increase of $68.9 \%$ over the control treatment and $35.5 \%$ over the $23 \mathrm{kgNha}^{-1}$.

The lowest grain yield was observed at the control treatment while the highest grain yield was at the nitrogen treatment of $46 \mathrm{kgNha}^{-1}$. There is a significant grain yield difference on durum wheat between the different rates of nitrogen treatment. In general an increase in nitrogen application rate had resulted in an increase of grain yield of durum wheat [18]. The highest (168kgha-1) and the lowest $\left(95 \mathrm{kgha}^{-1}\right)$ total $\mathrm{N}$ uptake (TNU) values were obtained from the application of $69 \mathrm{kgNha}^{-1}$ and control treatments, respectively. Increased $\mathrm{N}$ rates up to $69 \mathrm{kgha}^{-1}$ had increased total $\mathrm{N}$ uptake (TNU) and the lowest uptake was for the control treatment $\left(95 \mathrm{kgha}^{-1}\right)$. The highest grain protein content (GPC) (13\%) was recorded for the highest $\mathrm{N}$ rates $\left(69 \mathrm{kgNha}^{-1}\right)$. But no significant difference ( $\left.\mathrm{p}>0.05\right)$ for grain protein content was observed among the rest treatments. Generally, in this study among $\mathrm{N}$ rates no significant variations (P>0.05) for both DAS and DPM were observed.

Mean values for nitrogen rates showed, plant height had increased with each increment of nitrogen rates from control to the highest rate but no significant difference ( $p>0.05)$ was observed between the two higher $\mathrm{N}$ rates. This increase was probably due to availability of more nutrients, which helped in the maximum vegetative growth of the durum wheat plant and similar results of plant height increases with $\mathrm{N}$ rates increases were also reported elsewhere [19]. The application of different rates of nitrogen was significant $(\mathrm{P}<0.05)$ for grain yield indicating grain yield was influenced by $\mathrm{N}$ application rate differences. The large grain yield variation among different nitrogen treatments could help in the selection of better cultivars for different $\mathrm{N}$ supply environments. Biomass yield had increased with $\mathrm{N}$ rate increase from control to the highest level and similar result also reported elsewhere. The $\mathrm{N}$ rate significantly enhanced straw yield since $\mathrm{N}$ usually promotes the vegetative growth of the plant. From this study the result suggests that application of $69 \mathrm{kgNha}^{-1}$ seems reached economical with high grain yield production of durum wheat. Also, the application of $46 \mathrm{kgNha}^{-1}$ seems also adequate when one wants to minimize inorganic fertilizer input with modest compatible high grain yield. 


\section{Effect of INM on crop yields and productivity}

Many research findings have shown that neither inorganic fertilizers nor organic sources alone can result in sustainable productivity [20]. Furthermore, the price of inorganic fertilizers is increasing and becoming unaffordable for resource-poor smallholder farmers. The best remedy for soil fertility management is, therefore, a combination of both inorganic and organic fertilizers, where the inorganic fertilizer provides nutrients and the organic fertilizer mainly increases soil organic matter and improves soil structure and buffering capacity of the soil. The combined application of inorganic and organic fertilizers, usually termed integrated nutrient management, is widely recognized as a way of increasing yield and/or improving productivity of the soil sustainably. Several researchers have demonstrated the beneficial effect of integrated nutrient management in mitigating the deficiency of many secondary and micronutrients.

Identifying the optimum dose of integrated nutrient application is, however, required for maintaining adequate supply of nutrients for increased yield. Different recommendations on the rates of organic-inorganic fertilizer combination have been given for crop production in different parts of the world. Therefore, a judicious combination of organic and inorganic sources of nutrients may be envisaged as it addresses the problem of insufficient inorganic fertilizer supply and the large amount of organic material required for nutrient supply. Ethiopia is an importer of inorganic fertilizers. On the other hand, the country has high population of livestock and FYM is readily available. These scenarios necessitate the use of integrated nutrient management in crop production [21].

Under Ethiopian condition particularly in the highlands, integrated soil fertility management can give better yields as high as balanced application of fertilizer and significantly higher yields than the traditional cultivation method other than the integrated methods. For instance, in Benishangul Gumuz region a research done on word as Agalometi and Sirba indicates that a combination of few Agronomic management practices like tillage (not local type), application of manure and compost resulted in higher yields of different varieties of maize. In the study ploughing alone significantly $(\mathrm{P}<0.05)$ improved the average maize yield in 2002 from 7.9 to 9.5 tha $^{-1}$. Ploughing and adding either manure or compost also resulted in significantly higher yield in 2002 (10.1 and 10.0 tha $\left.^{-1}, \mathrm{P}<0.05\right)$. However, there was no significant difference among the three best treatments.

In Nitisols of South Ethiopia, a study by the Hawassa Agricultural Research Centre indicate that using Erythrina bruice as a green manure crop either its biomass alone or in combination with mineral fertilizer is found to increase the yield and yield components of bread wheat. E. bruice is a nitrogen fixing plant, which fix's the nitrogen through its leaves; this tree is endemic to Ethiopia and is a fast-growing nutrient rich plant particularly high with nutrient contents on NPK [22].

Combined data analysis of the two seasons revealed that there was a highly significant $(\mathrm{P}=0.0001)$ difference among treatments in their effect on grain yield of wheat. Application of 5 and 10 tha $^{-1}$ of $E$. bruci biomass significantly increased the grain yield of wheat by 82 and $127 \%$ over the control respectively. Similarly, application of the recommended dose of NP fertilizer (N46 \& P40) has significantly increased the grain yield by $145 \%$ over the control. There was no statistically significant difference between plots that received sole application of E. bruci biomass at 10 tha $^{-1}$ and recommended dose of NP fertilizers. However, the highest grain yield was obtained from plots that received combined application of E. bruci biomass + inorganic fertilizer applied at 10 tha $^{-1}+\mathrm{N} 23 \mathrm{P} 20,5 \mathrm{tha}^{-1}+\mathrm{N} 46 \mathrm{P} 40$ and 10ton $\mathrm{ha}^{-1}+\mathrm{N} 46 \mathrm{P} 40$. These treatments increased the grain yield of wheat by 173,190 and $227 \%$ over the control respectively.

It is a well-known fact that use of green manure increases the yield of crops, however it is not practical by most farmers, for most reasons that most trees provided for this purpose are exotic, and the trees are slow growing, and research attention is not given in this area, etc. Regardless being a fast-growing tree reaching up to $6 \mathrm{~m}$ height within 3 months, E. bruci has a very important agro-forestry attributes such as, spreading leaves, source of large quantities of swiftly decomposable litters, vigorous re-growth, copious coppicing as well as rapid recovery after a spell of prolonged drought [23]

In Western Hararghe, which is situated in Eastern Ethiopia, it is investigated that the major problem for decline in crop productivity is the decline in soil fertility. Since to recover the soil to its productive state it is not enough to apply mineral fertilizer alone, therefore integrated nutrient management is considered for the area. The Haramaya University then, in its four years study at Chiro campus (2008-2011) investigated the application of enriched Farm Yard Manure (FYM) in combination with mineral fertilizers can increase the productivity of hybrid maize (BH-140). Based on the study a combination of 4 ton ha- ${ }^{-1} \mathrm{FYM}+75 \mathrm{kgNha}^{-1}$ with $60 \mathrm{kgPha}^{-1}$ performed best among others, with maize yield of 8.16 tons ha-1. It is indicated also that application of 10 tons ha ${ }^{-1} \mathrm{FYM}$ alone can give as equal yield as 100 and $100 \mathrm{~kg} \mathrm{NP} \mathrm{ha}^{-1}$ together.

Not only the FYM in combination with mineral fertilizer is important in reversing soil fertility, but also the practice of minimum/zero tillage and residue management in combination with mineral fertilizer application is helpful in reversing soil fertility and hence the crop productivity. In a five years study (2000-2004) in western Ethiopia, the use of zero tillage with residue retention on the field (MTRR) is the best practice as compared to zero tillage with residue removal (MTRV) and the conventional tillage (CT) (Debele, no date). In the study three Nitrogen fertilizer rates are applied in combination with the tillage systems. The principal rate of nitrogen fertilizer being $92 \mathrm{~kg} \mathrm{~N} / \mathrm{ha}$ and the other two rates are $25 \%$ greater than and $25 \%$ less than the principal rate. Even if in the first two years there is no difference between MTRR and MTRV both of which are significantly higher than CT, in the next consecutive years the reality is reflected in that the yield of maize in MTRR went superior over the two MTRV and CT, this is due to a gradual build-up of soil fertility (Debele, no date). The study reflects that the integration of minimum/zero tillage and residue management together with mineral fertilizer gives an advantage over the conventional fertilizer application [24]. 
In some semi-arid regions of Ethiopia where there is shortage of soil moisture due to shortage of rainfall the use of tie-ridging at sowing period and application of mineral fertilizer increased the yield of sorghum. An experiment conducted in the Aberegalle subdistrict in Tigray region with split plot design on different Tillage practices and fertilizer applications have main plot treatments of shilshalo (traditional ridge without ties) for broadcasted planting (SBP), tied-ridging at planting (TROWAP), tied-ridging at four weeks after planting (TR4WAP), zero tillage (ZT), and shilshalo for row planting (SRP). Two fertilizer rates of nitrogen $(\mathrm{N})$ and phosphorus (P), as 0-0 N-P ha-1 (without fertilizer, F1) and $32-10 \mathrm{~kg}$ $\mathrm{N}-\mathrm{P}$ ha $^{-1}$ (with fertilizer, F2) treatments, are the sub-plots.

The result then indicated that tie-ridging in combination with fertilizer application is the best practice than other tillage practice even with fertilizer applications. The experiment conducted for two years (2002-2003) on two local sorghum varieties Woitozira and Chibal (Sorghum bicolor L. Moench) showed an increase in yield in range of $7-48 \%$ for tie-ridging at planting with fertilizer application relative to the other treatments. The main reason here is that the moisture conservation capability of the tillage practice, since the area is semi-arid tie-ridging starting from planting period is more advantageous than tie-ridging after four weak and ridging without tie making.

For an integration to be made there are a number of option even within one category for example, in manure application we can have enriched manure, farm yard manure, green manure and again taking green manure alone we can have many different options of legume crops that probably match the agro-climate, fast growing ability and easily decomposable. In Agro forestry system we can have alley cropping, hedge cropping, etc; within tillage system we can have zero tillage with residue retention or removal, minimum tillage and the conventional tillage, tie rigging or soil and water conservation measures such as couture cultivation, strip cropping, terracing, etc. organic matter management of the soil, compost application, use of high yielding germplasms; use of mineral fertilizer and a combination of some of this or many of them can help in reversing the decline in fertility of the soil and hence crop productivity, all of which should be done with active participation of the farmer.

In order to improve soil fertility and nutrient management approaches, on-farm integrated soil fertility management (ISFM) trials were conducted to evaluate the effects of organic and inorganic fertilizers on wheat (Triticum estivum L.) and tef (Eragrostis tef) yield and soil fertility in the highland Nitisol area of Ethiopia during 2010 and 2011 cropping seasons. The treatments were five selected combinations of $\mathrm{N}$ and $\mathrm{P}$, manure and compost. These included control, farmers' practice $\left(23 / 10 \mathrm{kgNPha}^{-1}\right)$, recommended NP rate $\left(60 / 20 \mathrm{kgNPha}^{-1}\right), 50 \%$ of recommended NP rate $\left(30 / 10 \mathrm{NPkg} \mathrm{ha}^{-1}\right)+50 \%$ manure and compost as inorganic $\mathrm{N}$ equivalence (3.25 tonsha $\mathrm{t}^{-1}$ ) and $50 \%$ manure $+50 \%$ compost as $\mathrm{N}$ equivalence.

From the above on-farm trial, results revealed that yields of wheat and teff, and some soil chemical properties significantly responded to the different soil fertility management treatments. Applications of inorganic and organic nutrient sources either alone or in combination had a significant $(\mathrm{p}<0.001$ and $\mathrm{p}<0.01)$ effect on grain yield, total biomass and harvest index of wheat, but not on its thousand grain weight. Higher wheat grain yield, total biomass and straw yield were obtained from the application of organic and inorganic plant nutrient sources. Yield increases were over $100 \%$, owing to soil fertility status improvement (Table 4). The application of recommended NP at the rate of $60 / 20 \mathrm{kgNPha}^{-1}$ increased wheat grain yield by about $151 \%$ and $85 \%$ compared to the control and the lowest farmers' NP rate respectively [25].

Table 4: Response of wheat grain yield (GY), total biomass (TBM), straw yield (SY), harvest index (HI) and thousand grain weight (TGW) to ISFM treatments.

\begin{tabular}{|c|c|c|c|c|c|}
\hline Treatments & $\begin{array}{c}\text { GY } \\
\left(\mathrm{kg} \mathrm{ha}^{-1}\right)\end{array}$ & $\begin{array}{c}\text { TBM } \\
\left(\mathrm{kg} \mathrm{ha}^{-1}\right)\end{array}$ & $\begin{array}{c}\text { SY } \\
\left(\mathrm{kg} \mathrm{ha}^{-1}\right)\end{array}$ & HI (\%) & TGW (g) \\
\hline Control & $1258^{\mathrm{e}}$ & $3644^{\mathrm{d}}$ & $2387^{d}$ & $34.5^{\mathrm{bc}}$ & 35.2 \\
\hline Farmers NP rate $(23 / 10)$ & $1713^{\mathrm{d}}$ & $4864^{c}$ & $2932^{c}$ & $35.2^{\mathrm{b}}$ & 34 \\
\hline Recommended NP rate $(60 / 20)$ & $3164^{\mathrm{a}}$ & $7678^{\mathrm{a}}$ & $4514^{\mathrm{a}}$ & $41.2^{\mathrm{ab}}$ & 33.2 \\
\hline $50 \%$ RNP $(30 / 10)+50 \%$ compost/manure $\left(3.25 \mathrm{t} \mathrm{ha}^{-1}\right)$ & $2882^{b}$ & $7073^{b}$ & $4192^{\mathrm{a}}$ & $40.8^{\mathrm{ab}}$ & 32.9 \\
\hline $50 \%$ manure $+50 \%$ compost $\left(6.5 t^{-1} a^{-1}\right)$ & $2646^{c}$ & $6219^{c}$ & $3574^{\mathrm{b}}$ & $42.5^{\mathrm{a}}$ & 34.9 \\
\hline LSD0.05 & 228.58 & 679.14 & 556.6 & 2.97 & 2.5 \\
\hline CV (\%) & 9.35 & 11.94 & 15.41 & 7.18 & 7.22 \\
\hline
\end{tabular}

${ }^{*}, * * *$ significant at $p<0.05$ and $p<0.001$, respectively; NS $=$ Not significant. Means in a column with the same letter are not significantly different $(p<0.05)$.

Similarly, application of half the recommended NP rate and half the recommended rate of manure and compost as inorganic $\mathrm{N}$ equivalence resulted in yield advantages of about $129 \%$ and $68 \%$ compared to the control and the lowest farmers' rate respectively. The results were presented in the table below.
The results of this study has clearly elucidated that if the application rate of fertilizers either as inorganic, organic or the combination of both is at least doubled under farmers' field condition. The yield gain will be more than double compared to the control plot and more than 50\% compared to the farmers' applied 
rate. Furthermore, the study proved the significance of the ISFM treatments containing both organic and inorganic forms under farmers' field condition that they could be considered as alternative options for sustainable soil and crop productivity in the degraded highlands of Ethiopia.

Results in the table below also indicated that productivity of teff was significantly affected by different soil fertility treatment levels. The crop responds well to fertilizer and crop management practices, where the highest teff grain yield was obtained with application of about $60 / 20 \mathrm{~kg} \mathrm{NP} \mathrm{ha}^{-1}$.
The application of the recommended inorganic NP fertilizer at the rate of $60 / 20 \mathrm{~kg} \mathrm{NP} \mathrm{ha}^{-1}$ increased teff grain yield and total biomass by about $141 \%$ and $149 \%$ compared to the control, and $44 \%$ and $53 \%$ compared to the farmers' NP rate respectively. Application of $50 \%$ recommended NP rate and $50 \%$ manure and compost as inorganic $\mathrm{N}$ equivalence resulted in grain yield and total biomass increments of $122 \%$ and $113 \%$ compared to the control, and $33 \%$ and $31 \%$ compared to the farmers' treatment $23 / 10 \mathrm{~kg}$ NP ha ${ }^{-1}$ ) (Table 5). A similar trend was observed in the teff grain yield and total biomass due to the application of full dose of manure and compost as inorganic $\mathrm{N}$ equivalence.

Table 5: Response of teff grain yield (GY), total biomass (TB), straw yield (SY) and harvest index (HI) to ISFM treatments on Nitisols of central Ethiopian highlands.

\begin{tabular}{|c|c|c|c|c|}
\hline Treatments & $\begin{array}{c}\text { GY } \\
\left(\mathrm{kg} \mathrm{ha}^{-1}\right)\end{array}$ & $\begin{array}{c}\text { TB } \\
\left(\mathrm{kg} \mathrm{ha}^{-1}\right)\end{array}$ & $\begin{array}{c}\text { SY } \\
\left(\mathrm{kg} \mathrm{ha}^{-1}\right)\end{array}$ & HI (\%) \\
\hline Control & $853^{\mathrm{d}}$ & $3232^{\mathrm{d}}$ & $2379^{d}$ & 26.4 \\
\hline Farmers NPK rate $(23 / 10 / 0)$ & $1427^{c}$ & $5250^{c}$ & $3824^{c}$ & 27.2 \\
\hline Recommended NPK rate $(60 / 20 / 0)$ & $2057^{\mathrm{a}}$ & $8050^{\mathrm{a}}$ & $5993^{\mathrm{a}}$ & 25.6 \\
\hline $50 \% \operatorname{RNPK}(30 / 10 / 0)+50 \%$ compost/manure $\left(3.25\right.$ t ha $\left.^{-1}\right)$ & $1896^{\mathrm{ab}}$ & $6895^{b}$ & $4998^{b}$ & 27.5 \\
\hline $50 \%$ manure $+50 \%$ compost $\left(6.5 t^{~ h a-1}\right)$ & $1795^{\mathrm{b}}$ & $6567^{\mathrm{b}}$ & $4773^{\mathrm{b}}$ & 27.3 \\
\hline LSD0.05 & 233 & 1077 & 900 & 3.4 \\
\hline CV $(\%)$ & 14.2 & 17.5 & 19.9 & 12 \\
\hline
\end{tabular}

The results of this study indicate that there is a potential to increase teff yield through improved soil fertility and crop management practices. This means that the fertility status of soils in the highlands of the country needs to be greatly improved so as to achieve the required output. On station and on-farm research findings indicate that up to 2.5 tons ha-1 of teff yield can be obtained under adequate fertilization and improved agronomic practices [21], while national average yield is yet about 1.17 tons ha-1. Similar results of agronomic trials showed that teff yield can be doubled by the combined use of high yielding varieties and applying both macro-and micro-nutrients such as zinc and copper.

\section{Effect of INM on soil physico-chemical properties}

Decline in soil fertility is one of the primary constraints to agricultural production in sub-Saharan Africa. In Kenya, farmers typically apply insufficient soil inputs, usually below the recommended rates. This along with poor agricultural practices has led to soil nutrient depletion estimated at $30 \mathrm{kgNha}^{-1}$ annually at district scales. Farmyard manure is the main way to manage soil fertility in central Kenya but is insufficient in quantity and poor in quality.

Major causes of nutrient depletion are farming without replenishing nutrients over time, and/or chemical imbalance issues such as soil acidity leading to fixation often driven by continuous cropping of cereals, removal of crop residues, leaching, low levels of fertilizer usage and unbalanced application of nutrients. Soil analytical data is important to identify the level of nutrients in the soil and to determine suitable rates and types of fertilizers for recommendation.

In general, the soil analysis results after crop harvesting revealed that integrated use of organic and inorganic nutrient sources could result in significant improvement in the overall condition of the soil as well as agricultural productivity if the best alternative option is adopted by producers. Kang et al. reported that the long-term application of organic manures in rice/cornwheat cropping system increased the index value as it increased the nutrient index, microbial index and crop index of soils.

Similar research findings also indicated that soils fertilized with manure had higher contents of organic matter and numbers of micro-fauna than fertilized soils, and were more enriched in $\mathrm{P}$, $\mathrm{K}, \mathrm{Ca}$ and $\mathrm{Mg}$ in topsoil and nitrate $\mathrm{N}, \mathrm{Ca}$ and $\mathrm{Mg}$ in sub soils [26]. Agegnehu et al. also reported that the soil $\mathrm{pH}$, total $\mathrm{N}$ and organic matter content, CEC and exchangeable cations were significantly improved due to the application of farmyard manure.

Many long-term studies have shown that combinations of both organic and inorganic nutrient sources lead to enhanced nutrient availability and synchronization of nutrient release and uptake by crops and positive effects on soil properties. However, the effects of 
applied materials vary with cropping systems, soil types, organic material management and environmental factors [27].

Soil degradation is the most serious bio-physical constraint limiting crop productivity in Ethiopia. The problem is more serious in the highlands where most of the human and livestock population is found. A recent study has showed that the average annual soil loss from agricultural land is estimated to be 137 tons ha-1 per year for the Ethiopian highlands, which is approximately an annual soil depth loss of $10 \mathrm{~mm}$ [28].

\section{Significance of integrated soil fertility management}

Integrated soil fertility management refers to a set of soil fertility management practices that necessarily include the use of chemical fertilizer, organic inputs, and improved crop varieties combined with the knowledge on how to adapt these practices to local conditions, aiming at maximizing agronomic use efficiency of the applied nutrients and improving crop productivity.

In Ethiopia, it is a well-known fact that, fertilizer recommendation is based on a national level, forwarded by the government, which is known as the blanket recommendation. This recommendation does not consider the local condition, regardless of the various researches done under different local conditions, hence it remained partially unsuccessful and it is thought by farmers that increasing yield through fertilizer application is very difficult and unachievable by their capacity. That is because the green revolution thought by the government of Ethiopia incurs the farmer in to high costs of fertilizers and pesticides, even if a credit facility is provided to the farmer, he/she cannot afford the cost as the yield obtained is not balancing it well. Moreover, the recommendation doesn't consider the farmers local condition.

Hence the principle of green revolution in Ethiopia under the blanket recommendation is not successful under most conditions, then more researches has to be done under farmers condition with his own participation in such a manner that the research is able to minimize the different sorts of local problems, by reducing the soil fertility loss and decline in productivity, under what is called the integrated soil fertility management $[29,30]$.

\section{Summary and Recommendation}

Soil erosion, continuous cultivation and low nutrient application are the major cause of decline soil fertility in Ethiopia. In some cases, the loss of organic matter together with the loss of top soil aggravates the problem of soil water retention resulting in moisture stress rather than nutrient deficiency. Due to high cost of fertilizer, most of the farmers in the country use less amount with blanket recommendation, this become complex for management due to intricate combinations of agro-climate, the soil, topography and the socio-economic condition of various locations. Therefore, the blanket recommendation and other fertilizer and pesticide application alone in Ethiopia are not a sufficient solution to the existing problem in the face of the farmer and in the face of reality. The solution should be the one which considers the complex interactions of Agro-climate, soil and the topographic environmental condition of the locality. Integrated soil fertility management is the best option to solve the existed soil nutrient problem. It is important to analyze the complex interactions and effects of the agro-climate, soil, and the environment with the various agronomic practices.

Integrated soil fertility management plays a critical role in both short-term nutrient availability and longer-term maintenance of soil organic matter and sustainability of crop productivity in most smallholder farming systems in the tropics. The results showed that the integrated application of organic and inorganic fertilizers improve productivity of crops as well as the fertility status of the soil. Nevertheless, though ISFM is the notably preferred option in replenishing soil fertility and enhancing productivity, it is not yet widely taken up by farmers. The reasons for this are many, which include access or availability of inputs, use of organic resources for other purposes in place of soil fertility, nutrient balancing, collecting, transporting and management of organic inputs and economic returns of investments. These are the key challenges of adoption in the scaling up of such alternative soil fertility management practices to millions of small-scale farmers in the country. There is a need, therefore, for research and extension to sort out issues of adoption and scaling up of the available options. In order to address soil fertility problems, potential synergies can be gained by combining technical options with farmers' knowledge as well as training of farmers and development agent on new soil fertility management approaches.

Generally, it is understood that the positive impacts of organic sources application on crop yield and soil properties can be realized after long term applications. In addition to improving the long-term productivity of the soil, this soil fertility management approach has resulted to a large cost saving of mineral fertilizers. Using organic fertilizers in combination with inorganic fertilizers has also shortened days to maturity, which is a good strategy to enable the plant to escape terminal moisture stress in rain-fed crop production. Thus, considering the poor soil fertility management by resource poor smallholder farmers and the high cost of mineral fertilizers, combined use of organic and mineral fertilizers at justifiable rates is central to enhance the productive capacity of the soil and to improve crop yield and productivity.

\section{References}

1. Mulatu D (1999) Agricultural technology, economic viability, and poverty alleviation in Ethiopia. Presented to the Agricultural Transformation Policy Workshop Nairobi, Kenya, p: 1-54.

2. UNDP (2002) UNDP assistance in the fifth country program to the agricultural sector.

3. Tareke B, Nigusse Z (2008) Results in a trial of system of teff intensification (sti) at debre zeit, Ethiopia, p: 1-2.

4. Yihenew G (2002) Selected chemical and physical characteristics of soil Adet research center and its testing sites in north-western Ethiopia.

5. Tekalign M, Selamyihun K, Mesfin A, Teklu E (2002) Review of the studies conducted on tef: Experience of the Alemaya University of Agriculture, Ethiopia, p: 22.

6. Tulema B, Jens BA, Tor AB (2007) Availability of organic nutrient sources and their effects on yield and nutrient recovery of tef [Eragrostis tef (Zucc.) Trotter] and on soil properties In J Plant Nutr Soil Sci 170(4): 543-550. 
7. Yu JK, Sun Q Rota ML, Edwards H, Tefera H, et al. (2006) Expressed sequence tag analysis in tef (Eragrostis tef (Zucc) Trotter). Genome 49(4): 365-372.

8. Palm CR, Myers RJK, Nadwwa SM (1997) Combined use of organic and inorganic sources for soil fertility maintenance and replenishment, In: RJ Brush (Ed.), SSSA special publication No. 51. Replenishing Soil Fertility in Africa. pp: 193-217.

9. Misra RV, Maheshwari S (1998) Integrated nutrient management in dry land. In: Unger PW, Sneed TV, Jordan WR, Jensen R (Eds.), Challenges in dry land agriculture. Proceedings of the international conference on dry land farming, Amarillo, Texas, USA, pp: 371-374.

10. Pender J, Place F, Ehui S (1999) Strategies for sustainable agricultural development in the Eastern African Highlands. EPD Discussion Paper No. 4, IFPRI, Washington, USA.

11. Abebe Y, Diriba B, Teshome T, Nega E, Ashenafi D (2005) Effects of Cajanus cajan biomass transfer and inorganic fertiliser on growth and yield of open pollinated maize variety on acidic nitosols of western Oromia, Ethiopia.

12. Amare G, Assaye D, Tuma A (2014) The response of Haricot Bean varieties to different rates of phosphorus at Arba Minch, Southern Ethiopia.

13. Attaullah K, Muhammad A, Asad S, Sajid A, Zahira H, et al. (2007) Evaluation of planting methods for grain yield and yield components of wheat. Sarhad J Agric 23(3): 561-563.

14. Brhan A (2012) Agronomic and Economic Effects of Blended Fertilizers Under Planting Method on Yield and Yield Components of Tef in Wereda Laelay maychew, Central Tigray, Msc thesis in Mekelle University, Ethiopia.

15. Daniel M (2006) Effects of integrated nutrient management on agronomic performance of potato (solanum tuberosum. L.) and fertility of Nitosol at Bako. Msc thesis, Alemaya University, Malaysia.

16. Elias E (2002) Farmers perceptions of soil fertility change and management. ISD and SOS-Sahel International (UK). EDM Printing Press, Addis Ababa, Ethiopia.

17. Ewulo BS, Ojeniyi SO, Akanni DA (2008) Effect of poultry manure on selected soil physical and chemical properties, growth, yield and nutrient status of tomato. African Journal of Agricultural Research 9: 612-616.

18. Eyasu E (2002) Farmers perceptions of soil fertility change and management. Paper presented to the evaluation in the tropics and subtropics.

19. Agegnehu G, vanBeek C, Bird MI (2014) Influence of integrated soil fertility management in wheat and teff productivity and soil chemical properties in the highland tropical environment. Journal of soil science and plant nutrition $14(3)$.
20. Hailu (2010) The effect of compost on soil fertility enhancement and yield increment under smallholder farming-a case of tahtai maichew district-tigray region, Phd dissertation, University of Hohenheim, Ethiopia.

21. Mugwe J, Mugendi D, Mucheru MM, Odee D, Mairura F (2009) Effect of selected organic materials and inorganic fertilizer on the soil fertility of a Humic Nitisol in the central highland s of Kenya. Soil use and Management 25(4): 434-440.

22. Müller SKM, Kotschi J (1994) Sustaining growth: Soil fertility management in tropical smallholdings, Margraf-Verlag, Weikersheim, Germany, pp: 486

23. Mengel, Konrad, Kirkby, Ernest A (1987) Principle of plant nutrition. (5 edn), Springer, Netherlands, pp: 360-376.

24. MOARD (Ministry of Agriculture and Rural Development) (2007) National fertilizer strategy and action plan of Ethiopia.

25. Tegene B (1998) Indigenous soil knowledge and fertility management practices of the Southern Wello Highlands. SINET: Ethiopia J Sci 31(1): 123-158.

26. Tewodros M, Belay Y (2015) Review on integrated soil fertility management for better crop production in Ethiopia. Sky Journal of Agricultural Research 4(1): 21-32.

27. Tilahun TF, Nigussie DR, Wondimu B, Setegn G (2013) Effect of farmyard manure and inorganic fertilizers on the growth, yield and moisture stress tolerance of rain-fed lowland rice. American Journal of Research Communication 1(4): 275-301.

28. World Bank (2007) Ethiopia: Accelerating equitable growth country economic memorandum. Part II Thematic Chapters - Report No. 38662-ET. World Bank Africa Region Poverty Reduction and Economic Management Unit, Washington DC, USA.

29. Woyema A, Bultosa G, Taa A (2012) Effect of different nitrogen fertilizer rates on yield and yield related traits for seven durum wheat (triticum turgidum l. Var durum) cultivars grown at Sinana, South Eastern Ethiopia, Ethiopia.

30. Yohannes G (1999) The use, maintenance and development of soil and water conservation measures by small-scale farming households in different agro-climatic zones of northern Shewa and Southern Wello, Ethiopia. SCRP Research Report 44. Centre for Development and Environment, University of Berne, Switzerland.
Creative Commons Attribution 4.0 International License

For possible submissions Click Here

\section{Submit Article}

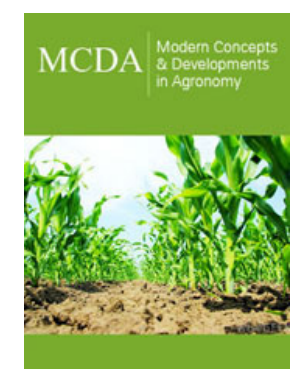

Modern Concepts \& Developments in Agronomy

\section{Benefits of Publishing with us}

- High-level peer review and editorial services

- Freely accessible online immediately upon publication

- Authors retain the copyright to their work

- Licensing it under a Creative Commons license

- Visibility through different online platforms 